\title{
TREATMENT OF DISTAL FRACTURES OF THE TIBIA
}

\author{
Pedro José Labronici ${ }^{1}$, José Sergio Franco ${ }^{2}$, Anselmo Fernandes da Sillva ${ }^{1}$, Felipe Martins de Pina Cabral ${ }^{1}$, \\ Marcelo da Silva Soares ${ }^{1}$, Paulo Roberto Barbosa de Toledo lourenço ${ }^{3}$, Rolix Hoffmann ${ }^{1}$, \\ Hélo Jorge Alvachian Fernandes ${ }^{4}$, Fernando Baldy dos Reis ${ }^{4}$
}

\begin{abstract}
Objective: to compare the results of fibula fixation (or non fixation) in the treatment of fractures located in the distal third of the tibia, by using intramedullary nailing and bridge plate. Method: 47 fractures on 47 patients were studied. Twenty-one patients were treated with non-reamed, interlocking intramedullary nailing, and 26 patients were treated with wide or narrow dynamic compression plates (using a minimally invasive technique). All of the fibular fractures were located at the same level or below tibial fractures. Results: in the group of patients treated with fibula fixation, the average healing time was 14.6 weeks. In the group of
\end{abstract}

patients treated without fibula fixation, the average healing time was 14.3 weeks. In the group of patients treated with fibula fixation a significantly smaller proportion of valgus angular deviation (6.3\%) was observed compared to the group of patients treated without fibula fixation (32.3\%). Conclusions: The benefits of fibula fixation remain controversial when tibial fractures are associated. Regarding fracture healing, there was no significant difference between the studied fracture groups.

Keywords: Osteosynthesis. Bone plates. Orthopedic pin. Tibia fracture.

Citation: Labronici PJ, Franco JS, Silva AF, Cabral FMP, Soares MS, Toledo PRBL et al. Treatment of distal fractures of the tibia. Acta Ortop Bras. [online]. 2009; 17(1):40-5. Available from URL: http://www.scielo.br/aob.

\section{INTRODUCTION}

Treating tibial distal third fractures is still a great challenge. Considering its anatomy, it is commonly difficult to achieve reduction and maintenance on these fractures. Reduction is even more difficult when a fibular fracture is found at the same level as the tibia. This fracture pattern reflects a high-energy mechanism of trauma causing an increased angular and rotational instability, limb shortening and soft parts injuries. , $^{1,2}$

In literature, several kinds of treatment for tibial distal third fractures are described..$^{3-8}$ However, two of the most used techniques are: locked intramedullary nail and minimally-invasive bridge plate. Intramedullary nails on tibial distal fractures are technically hard to perform and must be addressed with care. Failures in controlling distal fragments may lead to deformities and vicious union. ${ }^{3,9-11}$ Minimally-invasive bridge plate may be the optimal indication for these fractures, because it does not need large exposure areas for reduction. However, the failure to achieve an accurate pre-outline of the plate or a distraction of fracture fragments may result in angular deviations, vicious union and pseudoarthrosis..$^{12-17}$

The clinical impact of fibular fixation as an adjuvant to the treatment of tibial distal fractures treated with intramedullary nail or plates is still unknown. Some authors believe that fibular fixation would help to reduce rotational and sagittal alignment, which may be difficult to achieve with intramedullary nails alone. When a bridge plate is used on the tibia, fibular fixation would help to restore length and angular and rotational deformities, thus reducing the risk of vicious union. ${ }^{1,2,8,18}$

The objective of this study was to compare the results of fibular fixation or not when treating tibial distal third fractures with intramedullary nails and bridge plate.

\section{METHODS}

Between 1997 and 2005, 203 patients were treated for closed or open fractures grades I, II and IIIA on tibial shaft at Hospital Santa Teresa, Petrópolis. The patients were assessed by means of a protocol and the fractures were classified by the authors. There were 47 fractures on 47 patients, in 21 patients locked non-drilled intramedullary nail (Baumer ${ }^{\circledR}$ and universal nail $A O^{\circledR}$ ) was used and, in 26 patients, the bridge plate (wide or narrow dynamic compression plate) was used with a minimally-invasive technique. In patients treated with intramedullary nail, ages ranged from 17 to 57 years, mean: 33 years. In patients treated with bridge plate, ages ranged from 14 and 90 years, mean: 36 years.

In both techniques, data collected included demographic aspects, such as: age, gender, and tobacco use. Data concerning injury details, such as determinant mechanism of trauma, associated injuries, kind of fracture according to $\mathrm{AO}$ classification ${ }^{19}$ and whether to fixate fibula or not were included. (Table 1)

All authors state no potential conflict of interest concerning this article

1 - Prof. Dr. Donato D'Ângelo's Orthopaedics and Traumatology Service - Hospital Santa Teresa, Petrópolis/RJ, Brazil.

2 -UFRJ Medical School, Department of Orthopaedics and Traumatology -RJ, Brazil

3 - Hospital de Ipanema, Rio de Janeiro, Brazil.

4 - UNIFESP/EPM, Department of Orthopaedics and Traumatology, São Paulo, Brazil.

Correspondences to: Av. Roberto Silveira, 187 apto 601, - Petrópolis, RJ, Brasil. CEP: 25685-040. E-mail: plabronici@globo.com

Received in 09/25/07 approved in 05/04/08 
Table 1 - Global descriptive analysis of qualitative characteristics

\begin{tabular}{|c|c|c|c|}
\hline Variable & Category & $\mathrm{n}$ & $\%$ \\
\hline \multirow[t]{2}{*}{ Gender } & male & 37 & 78,7 \\
\hline & female & 10 & 21,3 \\
\hline \multirow[t]{2}{*}{ Side } & right & 22 & 46,8 \\
\hline & left & 25 & 53,2 \\
\hline \multirow[t]{6}{*}{ Cause of accident } & trampling & 12 & 25,5 \\
\hline & motorcycle & 16 & 34,0 \\
\hline & high fall & 13 & 27,7 \\
\hline & direct trauma & 3 & 6,4 \\
\hline & car accident & 2 & 4,3 \\
\hline & fall from stairs & 1 & 2,1 \\
\hline \multirow[t]{2}{*}{ Kind of fracture } & open & 15 & 31,9 \\
\hline & closed & 32 & 68,1 \\
\hline \multirow[t]{3}{*}{ Closed fracture } & 0 & 12 & 37,5 \\
\hline & 1 & 16 & 50 \\
\hline & 2 & 4 & 12,5 \\
\hline \multirow[t]{3}{*}{ Open fracture } & 1 & 7 & 46,7 \\
\hline & II & 7 & 46,7 \\
\hline & Illa & 1 & 6,7 \\
\hline \multirow[t]{2}{*}{ Smoker } & yes & 22 & 46,8 \\
\hline & no & 25 & 53,2 \\
\hline \multirow[t]{2}{*}{ Associated trauma } & yes & 5 & 10,6 \\
\hline & no & 42 & 89,4 \\
\hline \multirow[t]{3}{*}{ Classification } & A & 17 & 36,2 \\
\hline & B & 26 & 55,3 \\
\hline & C & 4 & 8,5 \\
\hline \multirow[t]{2}{*}{ Osteosynthesis type } & plate & 26 & 55,3 \\
\hline & nail & 21 & 44,7 \\
\hline \multirow[t]{2}{*}{ Fibular fixation } & yes & 16 & 34 \\
\hline & no & 31 & 66 \\
\hline
\end{tabular}

Source: Hospital Santa Teresa, Service Prof. Dr. Donato D'Ângelo, Petrópolis.

In the group of patients treated with fibular fixation, there were 10 males and six females, with seven presenting with fractures on right side and nine on the left side. According to AO classification $^{19}$ of fractures, three patients had type-A fracture, 11 type-B, and two type-C. Open fractures were classified by the method described by Gustilo et $\mathrm{al}^{20}$ and only one patient had an open fracture grade IIIA. Closed fractures were classified by the method of Oestern et al. ${ }^{21}$

Five patients had type-0 fracture, eight type-1, two type-2. No patient presented with type-3 fractures. (Figures 1 and 2)

In the group of patients treated without fibular fixation, there were 27 males, and four females, with 15 presenting with fractures on the right side and 16 on the left side. According to $A O$ classification ${ }^{19}$ of fractures, 14 patients had type-A fractures, 15 type-B, and two type-C. Open fractures were classified according to the method by Gustilo et $\mathrm{al}^{20}$ : seven patients had open fractures grade I and seven grade II. Closed fractures were classified by the method of Oestern et $a^{21}$ : seven patients presented with type-0, eight type-1, and two type-2. In both groups, fibular fracture was located at the same level or bellow tibial fracture. (Figures 3 and 4)
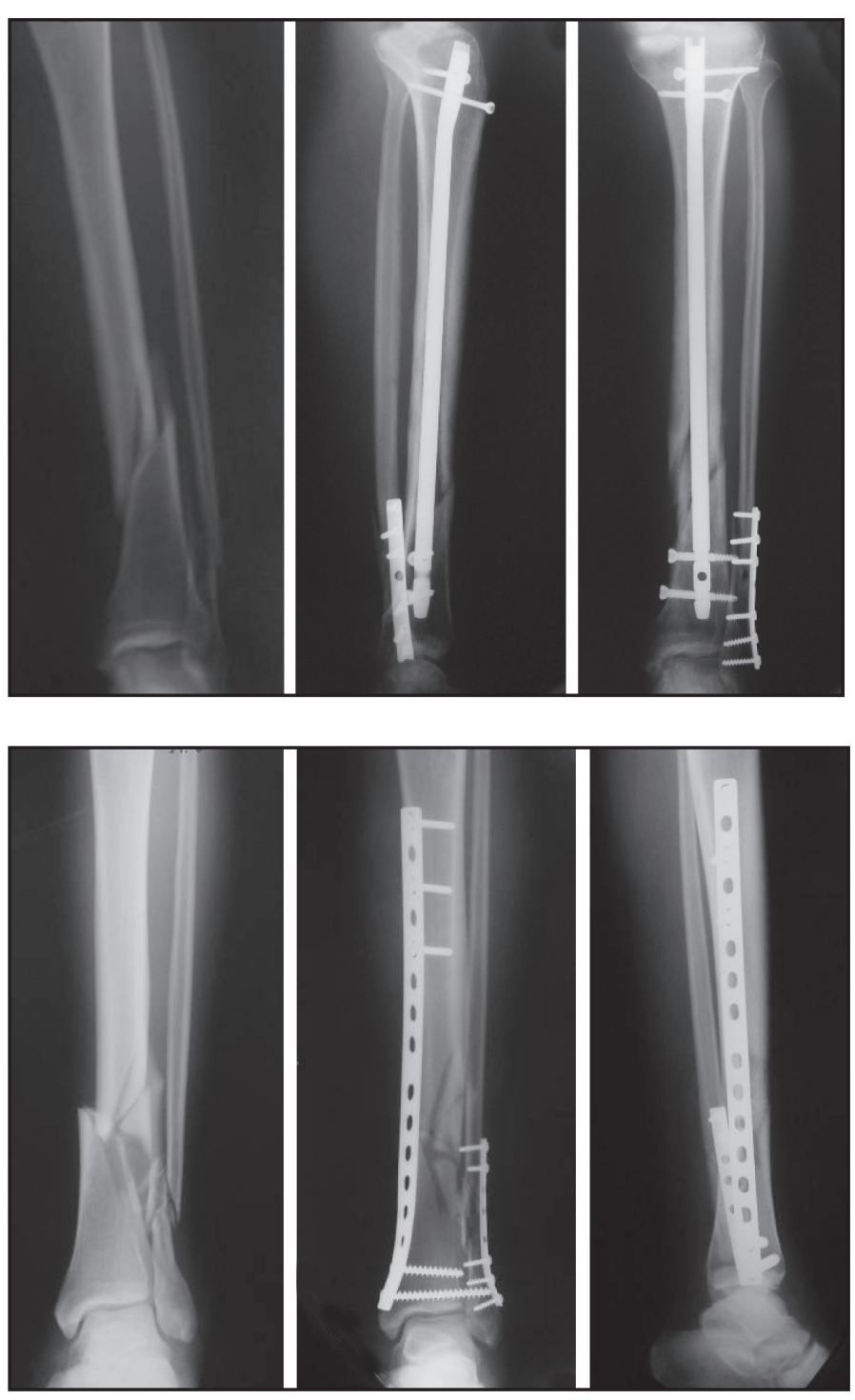

Figures 1 and 2 - Tibial distal fracture with fibular fixation

Angular deviations were classified according to Helfet et $\mathrm{al}^{(12)}$ in: < $5^{\circ}$ varus, $<10^{\circ}$ valgus and $<10^{\circ}$ antecurvate/ retrocurvate

\section{STATISTIC METHODOLOGY}

With the purpose of checking the existence or not of a significant correlation between variables with fibular fixation (either existent or not) the following methods were applied: for comparing quantitative data (numeric) the Mann-Whitney's (nonparametric) test was employed, and for comparing proportions (qualitative data) the chi-squared test $\left(\chi^{2}\right)$ or Fisher's exact test was applied.

A non-parametric method was employed, because some variables did not show normal distribution (Gaussian distribution) due to data dispersion and to the lack of symmetry on distribution. The criterion adopted for determining significance was the $5 \%$ level.

\section{RESULTS}

In the group treated with fibular fixation, the mean follow up time was 22.6 months, ranging from six to 48 months. Average time for union was 14.6 weeks, ranging from eight to 56 weeks. In the group treated without fibular fixation, the mean follow up time was 

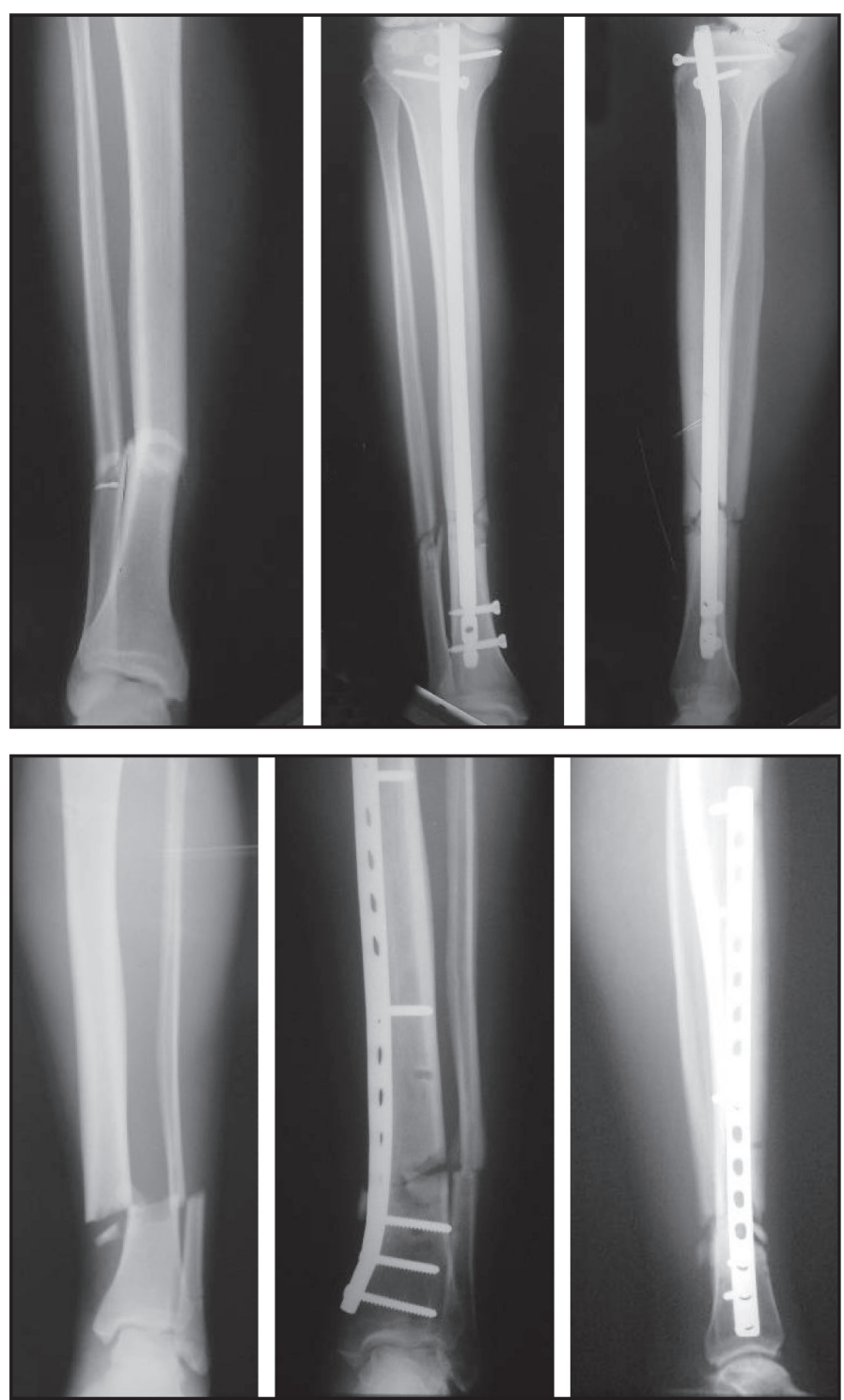

Figures 3 and 4 - Tibial distal fracture without fibular fixation

46.8 months, ranging from 10 to 112 months. Average time for union was 14.3 weeks, ranging from seven to 56 weeks. Therefore, time for union was similar in both groups. Table 2 provides mean values, standard deviation (SD), median, minimum and maximum for numeric variables according to fibular fixation, and to the correspondent descriptive level of the statistic test ( $p$ value). The statistical analysis was performed with the Mann-Whitney test, for variables as age, time interval between accident and surgery, follow up time, and union time.

We checked if there was any significant difference between group variables with and without fibular fixation. In the group of patients treated with fibular fixation, we found a proportion of closed fracture $(93.8 \%)$ significantly higher than the group without fibular fixation (54.8\%), with $p=0.007$, as shown by figure 5 .

The group of patients treated with fibular fixation showed a proportion of plate $(75 \%)$ significantly higher than the group without fibular fixation (45.2\%), with $p=0.05$, as shown by figure 6 .

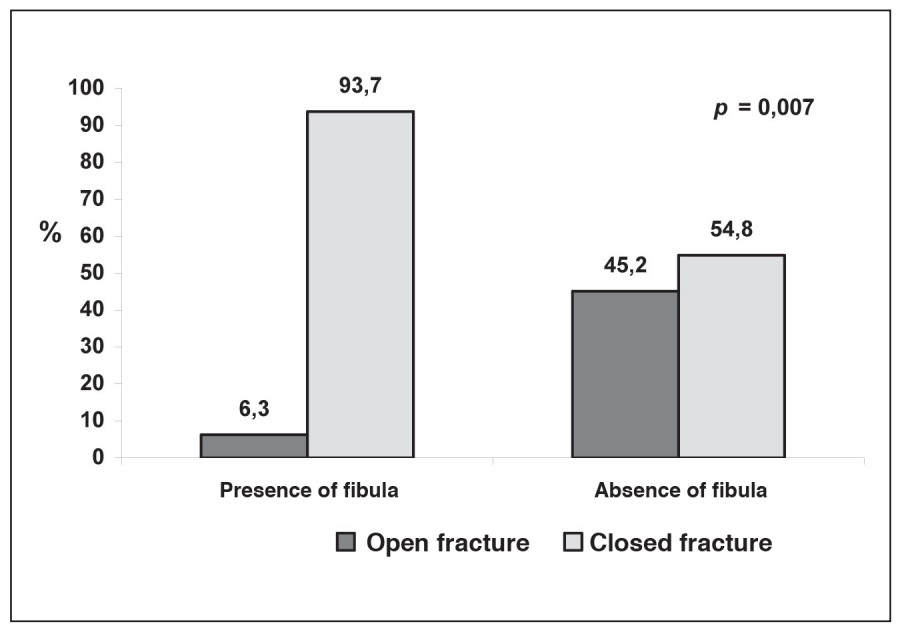

Source: Hospital Santa Teresa, Service Prof. Dr. Donato D’Ângelo, Petrópolis.

Figure 5 - Fibular fixation versus kind of fracture

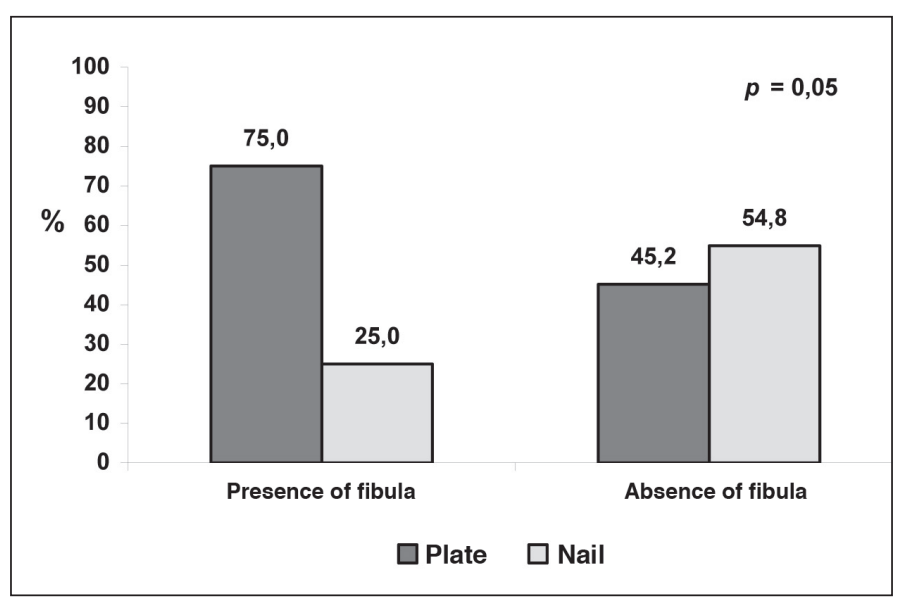

Source: Hospital Santa Teresa, Service Prof. Dr. Donato D’Ângelo, Petrópolis.

Figure 6 - Fibular fixation versus osteosynthesis type

Table 2 - Statistical analysis of numeric variables according to fibular fixation.

\begin{tabular}{l|c|c|c|c|c|c|c|c|}
\hline \multicolumn{1}{c|}{ Variable } & Fibula & $\mathbf{n}$ & Mean & SD & Median & Minimum & Maximum & p value \\
\hline Age (years) & yes & 16 & 41,1 & 18,1 & 36,5 & 18 & 90 \\
\hline & no & 31 & 32,1 & 12,5 & 31 & 14 & 57 \\
\hline Time accident-surgery (hours) & yes & 16 & 67,8 & 70,9 & 60 & 3 & 240 \\
\hline & no & 31 & 47,6 & 74,5 & 24 & 3 & 360 \\
\hline Follow up time (months) & yes & 16 & 22,6 & 16,5 & 20 & 6 & 48 \\
\hline & no & 31 & 46,8 & 27,4 & 36 & 10 & 112 & 0,0008 \\
\hline Union time (weeks) & yes & 16 & 14,6 & 11,4 & 12 & 8 & 56 \\
\hline
\end{tabular}

Source: Hospital Santa Teresa, Service Prof. Dr. Donato D’Ângelo, Petrópolis. 
In the group of patients treated with fibular fixation, we found a proportion of angular deviation in varus (6.3\%) significantly lower than the subgroup without fibular fixation (32.3\%), with $p=0.045$, and with angular deviation in valgus (62.5\%) significantly higher than the group with fibular fixation(32.3\%), with $p=0.047$, as shown by figures 7 and 8 and table 3 .

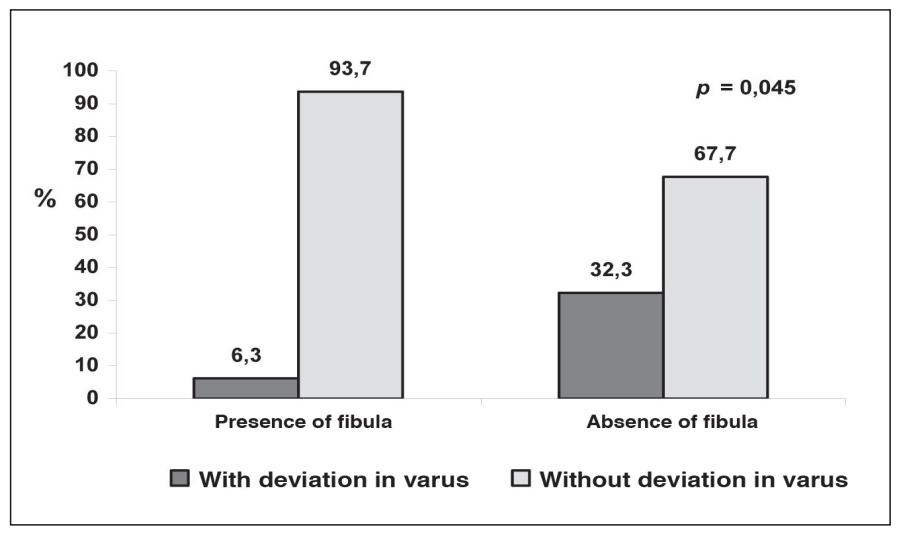

Figure 7 - Fibular fixation versus angular deviation in varus.

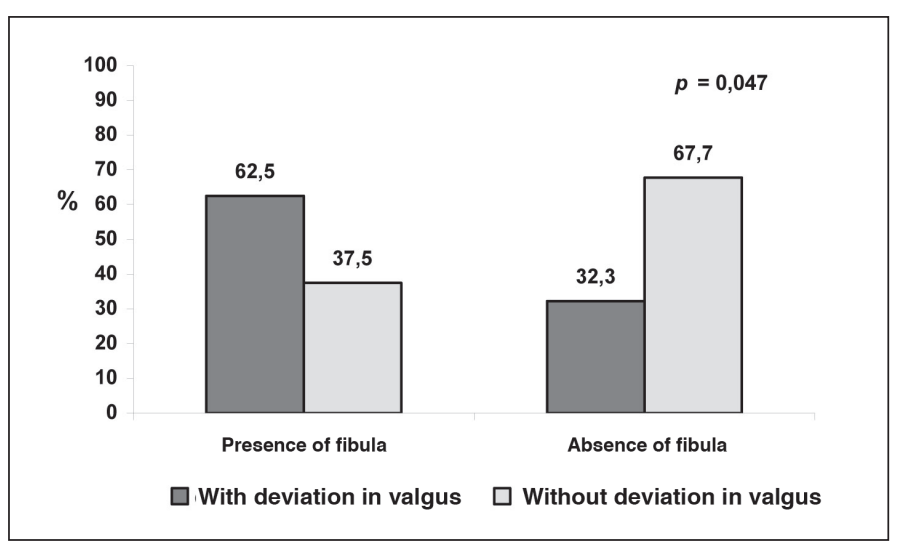

Source: Hospital Santa Teresa, Service Prof. Dr. Donato D’Ângelo, Petrópolis.

Figure 8 - Fibular fixation versus angular deviation in valgus.

Table 3 provides the frequency (n) and the percentage (\%) of the variables according to fibular fixation (either existent or not), and the correspondent descriptive level of the statistic test ( $p$ value). The statistical analysis was provided by $\chi^{2}$ test or by Fisher's exact test.

Table 3 - Statistical analysis of qualitative variables according to fibular fixation.

\begin{tabular}{|c|c|c|c|c|c|c|}
\hline \multirow[b]{3}{*}{ Variable } & \multirow[b]{3}{*}{ category } & \multicolumn{4}{|c|}{ Fibular fixation } & \multirow[b]{3}{*}{$p$ value } \\
\hline & & \multicolumn{2}{|c|}{ present } & \multicolumn{2}{|c|}{ absent } & \\
\hline & & $\mathrm{n}$ & $\%$ & $\mathrm{n}$ & $\%$ & \\
\hline \multirow[t]{2}{*}{ Gender } & male & 10 & 62,5 & 27 & 87,1 & \multirow{2}{*}{0,059} \\
\hline & female & 6 & 37,5 & 4 & 12,9 & \\
\hline \multirow[t]{2}{*}{ Side } & right & 7 & 43,8 & 15 & 48,4 & \multirow{2}{*}{0,76} \\
\hline & left & 9 & 56,3 & 16 & 51,6 & \\
\hline \multirow[t]{2}{*}{ Type of fracture } & open & 1 & 6,3 & 14 & 45,2 & \multirow{2}{*}{0,007} \\
\hline & closed & 15 & 93,8 & 17 & 54,8 & \\
\hline \multirow[t]{2}{*}{ Smoker } & yes & 7 & 43,8 & 15 & 48,4 & \multirow{2}{*}{0,76} \\
\hline & no & 9 & 56,3 & 16 & 51,6 & \\
\hline \multirow[t]{3}{*}{ Classification } & A & 3 & 18,8 & 14 & 45,2 & \multirow{3}{*}{0,17} \\
\hline & $\mathrm{B}$ & 11 & 68,8 & 15 & 48,4 & \\
\hline & C & 2 & 12,5 & 2 & 6,5 & \\
\hline \multirow[t]{2}{*}{ Classification } & A & 3 & 18,8 & 14 & 45,2 & \multirow{2}{*}{0,074} \\
\hline & $\mathrm{B} / \mathrm{C}$ & 13 & 81,3 & 17 & 54,8 & \\
\hline \multirow[t]{2}{*}{ Osteosynthesis type } & plate & 12 & 75,0 & 14 & 45,2 & \multirow{2}{*}{0,05} \\
\hline & nail & 4 & 25,0 & 17 & 54,8 & \\
\hline \multirow[t]{2}{*}{ Varus } & yes & 1 & 6,3 & 10 & 32,3 & \multirow{2}{*}{0,045} \\
\hline & no & 15 & 93,8 & 21 & 67,7 & \\
\hline \multirow[t]{2}{*}{ Valgus } & yes & 10 & 62,5 & 10 & 32,3 & \multirow{2}{*}{0,047} \\
\hline & no & 6 & 37,5 & 21 & 67,7 & \\
\hline \multirow[t]{2}{*}{ Anteversion } & yes & 7 & 43,8 & 8 & 25,8 & \multirow{2}{*}{0,21} \\
\hline & no & 9 & 56,3 & 23 & 74,2 & \\
\hline \multirow[t]{2}{*}{ Retroversion } & yes & 4 & 25,0 & 8 & 25,8 & \multirow{2}{*}{0,62} \\
\hline & no & 12 & 75,0 & 23 & 74,2 & \\
\hline \multirow[t]{2}{*}{ Varus or Valgus } & yes & 11 & 68,8 & 20 & 64,5 & \multirow{2}{*}{0,77} \\
\hline & no & 5 & 31,3 & 11 & 35,5 & \\
\hline \multirow[t]{2}{*}{ Ante- or retroversion } & yes & 11 & 68,8 & 16 & 51,6 & 020 \\
\hline & no & 5 & 31,3 & 15 & 48,4 & $0, \angle 0$ \\
\hline
\end{tabular}


Table 4 - Statistical analysis of angular deviations according to fibular fixation.

\begin{tabular}{|c|c|c|c|c|c|c|c|c|}
\hline Angular deviations (mm) & Fibula & $\mathrm{n}$ & Mean & SD & Median & Minimum & Maximum & $p$ value \\
\hline \multirow[t]{2}{*}{ Varus } & yes & 1 & 5,0 & - & - & - & - & \multirow{2}{*}{ few cases } \\
\hline & no & 10 & 4,2 & 1,8 & 4 & 2 & 6 & \\
\hline \multirow[t]{2}{*}{ Valgus } & yes & 10 & 4,9 & 2,6 & 5 & 2 & 10 & \multirow{2}{*}{0,42} \\
\hline & no & 10 & 6,8 & 4,4 & 5 & 2 & 15 & \\
\hline \multirow[t]{2}{*}{ Anteversion } & yes & 7 & 4,3 & 2,9 & 4 & 1 & 10 & \multirow{2}{*}{0,47} \\
\hline & no & 8 & 4,8 & 1,8 & 4,5 & 2 & 8 & \\
\hline \multirow[t]{2}{*}{ Retroversion } & yes & 4 & 4,8 & 2,4 & 4 & 3 & 8 & \multirow{2}{*}{ few cases } \\
\hline & no & 8 & 3,3 & 2,1 & 2,5 & 2 & 8 & \\
\hline \multirow[t]{2}{*}{ Varus or valgus } & yes & 11 & 4,9 & 2,5 & 5 & 2 & 10 & \multirow{2}{*}{0,85} \\
\hline & no & 20 & 5,5 & 3,5 & 4,5 & 2 & 15 & \\
\hline \multirow[t]{2}{*}{ Anteversion or retroversion } & yes & 11 & 4,5 & 2,6 & 4 & 1 & 10 & \multirow{2}{*}{0,67} \\
\hline & no & 16 & 4,0 & 2,0 & 4 & 2 & 8 & \\
\hline SD: standard deviation & & & & & & & & \\
\hline
\end{tabular}

Source: Hospital Santa Teresa, Service Prof. Dr. Donato D’Ângelo, Petrópolis.

There was a stronger trend to treat fractures type B or C (81.3\%) with fibular fixation compared to without fibular fixation (54.83\%), with $p=0.07$. There was also a stronger trend to treat women $(37.5 \%)$ with fibular fixation than in the group without fibular fixation (12.9\%), with $p=0.059$.

In this alternative analysis, the objective was to check the existence of differences in patients with angular deviation between groups with and without fibular fixation. (Table 4)

We found that there is no significant difference on angle levels between groups with and without fibular fixation for patients with deviation. This is because under a statistical point of view, the angle value is not an important factor, but the presence of deviation regardless of the angle, since only four patients (8.5\%) presented some kind of angle $\geq 10^{\circ}$.

\section{DISCUSSION}

Fractures of tibial distal third are difficult to treat. ${ }^{22}$ When associated to a poor lining of soft tissues, these fractures are frequently comminuted or present a small metaphyseal fragment. ${ }^{16}$ Traditionally, techniques fail to achieve an appropriate reduction and maintenance of fractures or may further damage soft parts. ${ }^{23}$ Biological fixation of tibial distal third fractures is beneficial and technically feasible. The advantages are : it reduces injuries on soft parts, it does not compromise bone vascularization and presents a low complication rate, especially when compared to open reduction and internal fixation. 12,24,25 These fractures, when not involving joints, may be treated by two different manners: Locked intramedullary nail with or without milling ${ }^{3,9-11}$ or bridge plate using a minimally invasive technique. ${ }^{12-17}$

Treating tibial distal third fractures associated to fibular fracture at the same level becomes even more difficult. This fracture pattern reflects a high-energy mechanism of trauma causing an increased rotational instability and soft parts rupture. ${ }^{1}$ Another clinical concern was the feasibility of the inter-bone membrane. When fibula is fractured at the same level of the tibia, the inter-bone membrane may not remain intact and, as a result, the distal fragment of the fracture can move to varus or valgus due to the lack of membrane stability. ${ }^{1}$

Biomechanical studies in cadavers showed that fibular fracture fixation associated to tibial distal fracture treated with locked intramedullary nail reduces angular deviations and vicious union. It also helps to avoid the windshield wiper effect between locking screw and the nail hole, which favors varus-valgus movements of the screw. ${ }^{1}$ Mosheiff et al. ${ }^{8}$ and Tyllianakis et al. ${ }^{18}$ treating with fibular fixation, reported a low trend of tibial deformities, because they believe that the alignment of the limb during nail placement is easy. Dogra et al. ${ }^{26}$ reported that, in three patients of the 15 cases of their series presented angle in varus or valgus $>5^{\circ}$, without fibular fixation. Schmidt et al. ${ }^{27}$ reported that fibular fixation must be performed before fixating tibia with intramedullary nail when there is a major fibular deviation, because this helps on restoring the alignment of the limb or when there is tallus instability. However, they believe that fibular fixation contributes to morbidity increase. Goldsztajn et al. ${ }^{28}$ treated 26 patients with milled intramedullary nail and found $88.5 \%$ of anatomical reduction of the tibia at early postoperative period, without requiring fibular fracture fixation.

Fibular fracture fixation associated to tibial distal fracture treated with bridge plate by a minimally invasive technique, should be evaluated on an individual basis, because accurate indications have not been established yet. ${ }^{2}$ Although not usually fixing fibula, Bedi et $\mathrm{al}^{2}{ }^{2}$ showed that this technique helps on restore limb length by correcting angular and rotational deformities on fibular fractures with major deviations or comminution, thus, reducing the risk of vicious union. In our study, fractures treated with fibular fixation associated to tibial fractures treated with intramedullary nail helped to reestablish length, angular deviations (valgus) and limb rotation especially on types B and C fractures according to $\mathrm{AO}$ classification, even when we use the technique by Schmitt et al. ${ }^{29}$, which uses a Kirschner wire in parallel to ankle joint. With this wire as a reference, in addition to help on reducing tibial fracture, it also guides the accurate nail placement, which must be 
placed at a straight angle with this wire. When we use the bridge plate, fibular fixation, in addition to help on restoring limb length and on correcting angular and rotational deformities, kept a good limb anatomy and made pre-modeling of the plate easier, helping on reducing fracture and avoiding the most common deformity in valgus. This deformity was significantly stronger in patients not treated with fibular fixation both with intramedullary nails and bridge plates.
Our results also reinforce the concept that fibular fixation associated to tibial distal third fracture treatment does not have any effect on bone union, which is consistent with literature. ${ }^{26,27}$

\section{CONCLUSION}

The benefits of fibular fixation remain controversial when there are associated tibial fractures. Concerning union, no significant differences were found.

\section{REFERENCES}

1. Kumar A, Charlebois SJ, Cain EL, Smith RA, Daniels AU, Crates JM. Effect of fibular plate fixation on rotational stability of simulated distal tibial fractures treated with intramedullary nailing. J Bone Joint Surg Am. 2003; 85:604-8.

2. Bedi A, Le TT, Karunakar MA. Surgical treatment of nonarticular distal tibia fractures. J Am Acad Orthop Surg. 2006; 14:406-16.

3. Robinson CM, McLauchlan GJ, McLean IP, Court-Brown CM. Distal metaphyseal fractures of the tibia with minimal involvement of the ankle: Classification and treatment by locked intramedullary nailing. J Bone Joint Surg Br. 1995; 77: 781-787.

4. Gorczyca JT, McKale J, Pugh K, Pienkowski D. Modified tibial nails for treating distal tibia fractures. J Orthop Trauma. 2002; 16: 18-22.

5. Trafton PG: Tibial shaft fractures, in Browner BD, Levine AM, Jupiter JB (eds): Skeletal Trauma, ed 3. Philadelphia, PA: WB Saunders, 2003, vol 2, p 2131-256.

6. Sarmiento A, Latta LL: 450 closed fractures of the distal third of the tibia treated with a functional brace. Clin Orthop Relat Res 2004; 428:261-71.

7. Bourne RB: Pylon fractures of the distal tibia. Clin Orthop Relat Res. 1989; 240:42-6

8. Mosheiff R, Safran O, Segal D, Liebergall M. The unreamed tibial nail in the treatment of distal metaphyseal fractures. Injury. 1999; 30:83-90.

9. Konrath G, Moed BR, Watson JT, Kaneshiro S, Karges DE, Cramer KE. Intramedullary nailing of unstable diaphyseal fractures of the tibia with distal intraarticular involvement. J Orthop Trauma. 1997; 11:200-5.

10. Tornetta III P, Casey D, Creevy WR. Nailing proximal and distal tibia fractures. Rosemont, IL: Orthopaedic Trauma Association. Final Program \& Membership Directory. 2000: 131-132.

11. Richter D, Ostermann PA, Ekkernkamp A, Hahn MP, Muhr G. Distal tibial fracture: An indication for osteosynthesis with an unreamed intramedullary nail? [German] Langenbecks Arch Chir Suppl Kongressbd. 1997; 114:1259-61.

12. Helfet DL, Shonnard PY, Levine D, Borrelli J Jr. Minimally invasive plate osteosynthesis of distal fractures of the tibia. Injury. 1997; 28(suppl 1): A42-A47.

13. Oh CW, Kyung HS, Park IH, Kim PT, Inn JC. Distal tibia metaphyseal fractures treated by percutaneous plate osteosynthesis. Clin Orthop Relat Res. 2003; 408:286-91.

14. Francois J, Vandeputte G, Verheyden F, Nelen G. Percutaneous plate fixation of fractures of the distal tibia. Acta Orthop Belg 2004. 70:148-54.

15. Borg T, Larsson S, Lindsjo U. Percutaneous plating of distal tibial fractures:
Preliminary results in 21 patients. Injury 2004; 35:608-14

16. Maffulli N, Toms AD, McMurtie A, Oliva F. Percutaneous plating of distal tibial fractures. Int Orthop. 2004; 28:159-62.

17. Khoury A, Liebergall M, London E, Mosheiff R. Percutaneous plating of distal tibial fractures. Foot Ankle Int. 2002; 23:818-24.

18. Tyllianakis M, Megas $P$, Giannikas D, Lambiris E. Interlocking intramedullary nailing in distal tibial fractures. Orthopedics. 2000; 23:805-8.

19. Müller ME, Allgöwer M, Schneider R, Willenegger H. Manual de Osteossíntese: Técnicas Recomendadas pelos Grupos AO-ASIF. 3a ed. São Paulo: Manole 1993. p.151-8. Tradução: Nelson Gomes de Oliveira.

20. Gustilo RB, Anderson JT. Prevention of infection in the treatment of one thou sand and twenty-five open fractures of long bones: retrospective and prospective analyses. J Bone Joint Surg Am. 1976; 58:453-8.

21. Oestern HJ, Tscherne H. Pathophysiology and classification of soft tissue injuries associated with fractures. In: Tscherne $H$, Gotzen $L$ (eds): Fractures with soft tissue injuries. Berlin: Springer-Verlag; 1984. p. 1-9.

22. Thordarson DB. Complications after treatment of tibial pilon fractures: prevention and management strategies. J Am Acad Orthop Surg. 2000; 8:253-65.

23. Bonar SK, Marsh JL. Tibial plafond fractures: changingprinciples of treatment. J Am Acad Orthop Surg. 1994; 2:247-54.

24. Farouk O, Krettek C, Miclau T, Schandelmaier P, Guy P, Tscherne H. Minimally invasive plate osteosynthesis and vascularity: Preliminary results of a cadaver injection study. Injury. 1997; 28(suppl 1): A7-A12.

25. Krettek C. Concepts of minimally invasive plate osteosynthesis. Injury. 1997; 28(suppl 1): S-A1-S-A2.

26. Dogra AS, Ruiz AL, Thompson NS, Nolan PC. Dia-metaphyseal distal tibial fractures - treatment with a shortened intramedullary nail: a review of 15 cases. Injury. 2000; 31:799-804

27. Schmidt AH, Finkemeier CG, Tornetta III P. Treatment of closed tibial fractures. Instructional Course Lectures, the American Academy of Orthopaedic Surgeons. J Bone Joint Surg Am. 2003; 85:352-68

28. Goldsztajn F, Guimarães JM, Rocha TH, Correa M, Dias MV, Lemgruber L. Fraturas do terço distal dos ossos da perna: É necessário fixar a fíbula? Congresso Brasileiro de Trauma. Santos, SP, 2007.

29. Schmitt AK, Nork SE, Winquist RA. Intramedullary nailing of distal metaphyseal tibial fractures. Read at the Annual Meeting of the Orthopaedic Trauma Association 2000; 13: San Antonio, Tx. 